\title{
鼓膜の異常陥凹と耳管障害
}

\author{
藤田 明彦・倉田 響介 \\ 高橋 晴雄・本庄㟶
}

\section{Abnormal Retraction of Eardrums and Eustachian Tube Dysfunction}

\author{
Akihiko Fujita, Kyosuke Kurata, Haruo Takahashi and Iwao Honjo \\ (Kyoto University)
}

Tympanic membrane retraction is one of the important sequelae of otitis media with effusion (OME). In this study, the mechanism of atelectasis of the eardrums was investigated from the point of view of eustachian tube dysfunction.

One hundred and six ears with refractory OME which were not cured by the age of 10 were examined, because many refractory OME cases exhibit various types of tubal dysfunction, including stenosis and excessive patency.

When the relationship between passive tubal function and retraction of the eardrum was examined, the incidence of retraction was found to be significantly higher in ears with low opening pressure of the eustachian tube. Twenty five ears with tubal closing failure, evaluated by the sniffing test, showed a significantly higher incidence of tympanic membrane retraction than did those without evidence of closing failure.

These results suggest that retraction of the eardrum is closely related to excessive patency or closing failure of the eustachian tube.

Key words: atelectatic ear, eustachian tube dysfunction, closing failure, sniffing test

はじめに

癒着性中耳炎や中耳真珠腫の一部が鼓膜の内

陷を発症の契機とすることは明らかであり，こ れらの疾患と鼓膜陥凹をしばしば生じる滲出性 中耳炎との関係は長く議論されてきた。しかし 滲出性中耳炎はその多くが治癒に至る疾患であ り, このなかのどの症例が高度の鼓膜陥凹病変 を示すのかは未だ充分明らかではない，鼓膜内 陥のメカニズムとして, 従来から炎症による二 次的な鼓膜の萎縮1), 耳管障害による中耳の陰 圧化 ${ }^{2)}$, あるいは鼓室狭部の閉塞 ${ }^{3)}$ が挙げられ
てきたが，我々はこの中でも耳管障害の因子が 鼓膜陥凹にどのようにかかわっているかに焦点 を絞って検討を行った.

ここで一般の小児參出性中耳炎の耳管障害の 特徵が，中耳陰圧を嚥下で解除できない動的な 機能障害にあることに対(4)5)，10歳以降にま で治癒が遷延する青少年期のいわゆる難治性㳂 出性中耳炎では，耳管の狭窄や病的な開放など 多彩な耳管障害がみられ ${ }^{6)}$, 耳管障害と鼓膜陥 凹との関係を明らかにするのに都合の良い対象 といえる。 
そこでまず難治性滲出性中耳炎例と一般の小 児滲出性中耳炎例との間で鼓膜病変の程度を比 較し, 次いで難治性出性中耳炎例の中で耳管 の器質的異常と病的鼓膜陥凹との関係を知ろう とした.

\section{対象と方法}

対象：10歳以降にまで治瘉が遷延した難治性 滲出性中耳炎77例106耳 $(10 \sim 20$ 歳, 平均 13.4 歳)，拈よび対照として $4 \sim 8$ 歳の小児滲出性 中耳炎130例244耳(平均6.1歳)である.

鼓膜陥凹の程度判定 : 処置用顕微鏡下に弛緩 部と緊張部とに分けて評価した。鼓膜弛緩部に ついては Tos 分類 II 度7) (鼓膜弛緩部とッチ骨 に癒着がみられるもの) 以上を有意の鼓膜陥凹 とし, 鼓膜緊張部については Sade 分類 II 度 ${ }^{8)}$ （鼓膜が内宿してキヌタ骨またはアブミ骨に接 触しているもの)以上を陥凹ありと判定した。

耳管機能検査 : 鼓膜穿孔を介した受動的な耳 管の開大圧と, 耳管の閉鎖障害の一つの指標で ある「鼻すすりテスト」を行った。耳管開大圧 の正常值は, 外傷性鼓膜穿孔 33 耳の結果から 165 545ミリ水柱 (平均 355 ミリ水柱, 標準偏差 190 ミリ水柱）とした5). な招今回の対象は滲出 性中耳炎例であり, 動的な耳管換気能の障害は 全症例共通の特徵であるため, 分析のための因 子から除外した。

\section{結 果}

1．鼓膜陥凹の出現頻度

1) 鼓膜弛緩部：難治性滲出性中耳炎群では $37 \%$ (39耳) 飞 Tos 分類 II 度以上の陥凹がみら れ，小児渗出性中耳炎群のそれ(6.6\%，16耳) と比べて有意に高頻度であることがわかった (図 $1, \chi^{2}$ 検定, $\chi=48.7, \mathrm{p}<0.01$ ).

2 ）鼓膜緊張部：Sade 分類 II 度以上の陥凹 を示したのは難治群では22\%(23耳)で，小児滲 中群では $4.6 \%$ (11耳)であり, 両者間に有意の 差が得られた(図 $2, \chi^{2}$ 検定, $\chi=23.0, \quad \mathrm{p}<$ 0.01). また難治性滲出性中耳炎で, 鼓膜の弛 緩部あるいは緊張部の少なくとも一方に有意の 鼓膜樎凹がみられる頻度は $42 \%$ (44耳) に及び，
滲出性中耳炎難治例と中耳炎後遺症との密接な 関係が示唆された。

\section{2. 耳管障害と喆膜陥凹}

難治性出性中耳炎106耳の耳管開大圧は， 高値を示したもの33耳，正常範囲59耳，低値を 示したもの14耳であった。

1) 耳管の通過性と鼓膜弛緩部陷凹の関係： 図 3 のように, 通気圧高値の例と正常範囲の例 では，それぞれ24\%(8/33耳)，34\%(20/59耳) で有意の陥山がみられ，一方通気圧が低い例で はこれが79\%(11/14耳)に達した。

2 ）耳管の通過性と鼓膜緊張部陥凹の関係 : 図 4 の上5に, 通気圧高值例, 正常例, 低值例 でそれぞれ陥凹率は $9 \%$ (3/33耳)，17\% (10/59 耳), $71 \%(10 / 14$ 耳) であり，耳管通気圧低值例 で有意に鼓膜陥凹の頻度が高いことがわかった $\left(\chi^{2}\right.$ 検定, 弛緩部 : $\chi=3.5, \mathrm{p}<0.05$, 緊張部 : $\chi=9.5, \mathrm{p}<0.01)$.

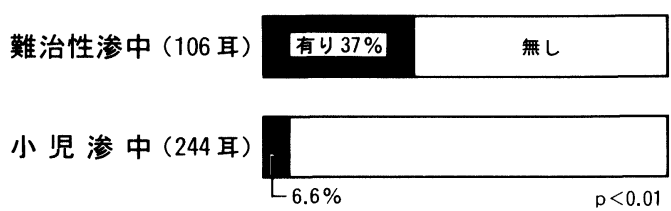

図 1 鼓膜弛緩部陥凹の出現率

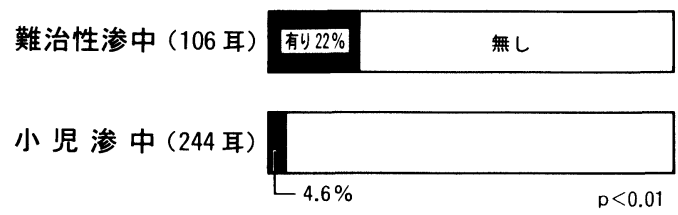

図 2 鼓膜緊張部陥凹の出現率

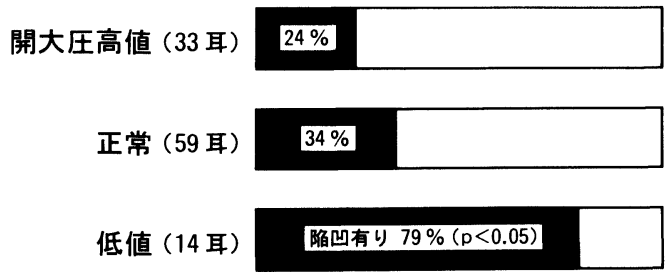

図 3 耳管開大圧と鼓膜驰緩部陥凹 （難治性滲出性中耳炎例106耳） 
3 ）耳管の閉鎖障害と鼓膜陥凹との関係 : 難 治性參出性中耳炎で鼻すすりテストが行われた 105耳の中で, 鼻すすりにより中耳に陰圧が生 じたのは25耳で，この中で鼓膜弛緩部に有意の 陷凹がみられたのは $56 \%$ (14耳), 鼓膜緊張部に

開大圧高値 (33耳) $9 \%$

正常 (59耳) $17 \%$

\section{低値（14 耳） 陌凹有り $71 \%(p<0.01)$}

図 4 耳管開大圧と鼓膜緊張部陥凹 （難治性參出性中耳炎例106耳）

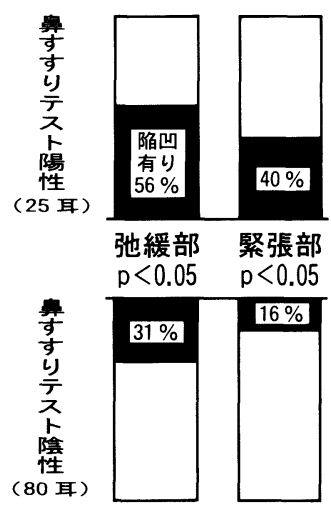

図 5 耳管の閉鎖障害の有無と鼓膜陥凹 (難治性出性中耳炎例105耳)

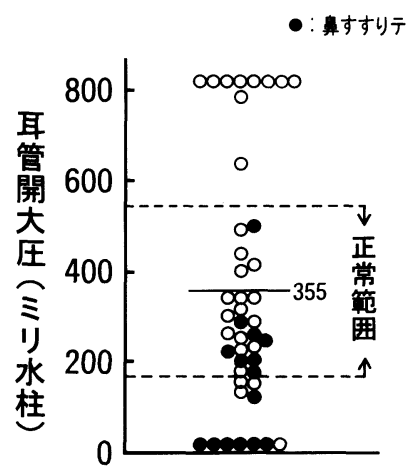

図 6 鼓膜高度陥凹例の耳管通過性 (44耳)
陷凹がみられたのは40\%(10耳)であった。これ

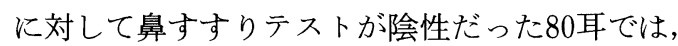
弛緩部陥凹例は $31 \%(25 耳)$, 緊張部でも 16 \%(13耳)にとどまり, 鼻すすりテスト陽性例で 有意に鼓膜陥凹例の多いことがわかった (図 $5, \chi^{2}$ 検定, 弛緩部: $\chi=4.0, \mathrm{p}<0.05$, 緊 張部: $\chi=5.0, \mathrm{p}<0.05)$. 以上の結果から鼓膜 の内陥が耳管の狭窄よりむしろ, 耳管開放や鼻 すすりと関係することが示唆された。 これを明 らかにするため, 鼓膜が高度に陥凹した 44 耳に ついて，耳管開大圧と鼻すすりテストの結果を 同じグラフ上に示すと (図 6 ), 耳管開大圧が正 常範囲にある例でもとの法とんどが平均開大圧 （355ミリ水柱）上り低い値を示し，鼻すすりテ ストも陽性例が多いことがわかった。

\section{考案}

従来鼓膜内陷のメカニズムとして耳管障害に よる中耳の陰圧化や, 鼓室狭部の閉塞による乳 突洞内の陰圧が鼓膜に作用して生じるとする考 え, あるいは滲出性中耳炎の持続による鼓膜固 有層の变化が鼓膜の萎縮を来し，その内陥を助 長するなどの説明があった。 しかし滲出性中耳 炎で実際に圧トランスデューサーで測定した中 耳陰圧は100ミリ水柱以内をとる例が多く9)10), この程度の中耳陰圧だけで鼓膜の高度陥凹や瘉 着に至るとは考えがたい。また高橋 ${ }^{10)}$ (動物 実験の結果から, 臨床的にみられる耳管の動的 換気能の障害だけでは，多くは軽度の中耳陰圧 にとどまることを示して和り，この因子では鼓 膜の高度陷凹に至らないことがわかる. 一方 Magnuson $^{11)}$ は, 真珠腫例や瘉着性中耳炎で耳 管の閉鎖障害がしばしばみられることを報告し， 「鼻す寸り」で形成される中耳腔の陰圧が真珠 腫の成因として重要であると述べている，今回 の我々の結果はこの考えを支持するものであり， 耳管開大圧の低い例や鼻すすりテスト陽性例で 高度の鼓膜内陥が多くみられたことから, 耳管 の閉鎖障害がその成因として重要であることが 示された.

今回の対象で鼓膜の高度陥凹を伴ら鼻す寸り 
テスト陽性例は 15 耳あり，これらで $2 \sim 3$ 回の 鼻すすりで生じた中耳陰圧は一 50 ミリ水柱から -350 ミリ水柱まで, 平均は一 144 ミリ水柱であ った(図 7 )。一方我々が鼻すすりテストに用い た耳管機能測定回路の容積は約 $10.3 \mathrm{ml}$ であり, 同時に volumetric method ${ }^{12)}$ で計測した患耳の 外耳道・中耳腔容積 ( 13 耳) が $1.8 \sim 8.9 \mathrm{ml}$, 平 均 $4.8 \mathrm{ml}$ と極めて小容積であることを考慮す ると, これらの陰圧は鼓膜に穿孔がない場合， 数倍の高度陰圧が形成されると考兄られる.

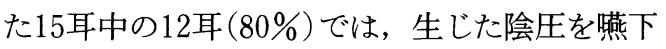
で解除できなかった(ロック現象).

今回の結果から鼓膜の内陥を来す危険因子と して，耳管の開放ないしは閉鎖障害がまず考え られた。しかし一方では鼻すすりテストが陽性 であるにもかかわらず高度の鼓膜陥凹を示さな い例があることや，その逆に耳管開大圧が正常 あるいは狭窄例でも少数ながら鼓膜陥凹例があ る事実から, 鼓膜内陥の成立には耳管障害以外 にも例えば豉膜の強度の個体差など, 複数の因 子が関与するものと考觉られる.

\section{まとめ}

1.10歳以降にまで遷延した難治性出性中 耳炎では, 小児例と比較して鼓膜の陥凹性病变 が有意に多くみられた。

2. 鼓膜の内陷を来寸危険因子として, 耳管 の異常な開放や閉鎖障害が考えられた.

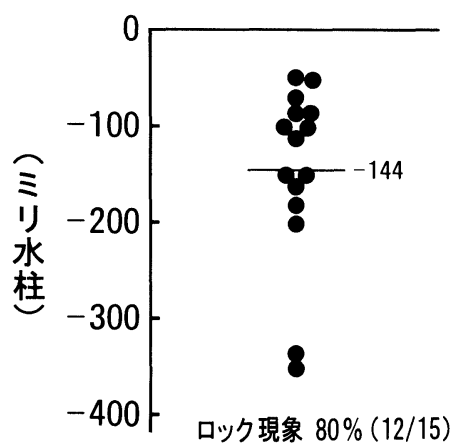

図 7 「鼻すすり」テスト陽性例で生じた中 耳陰圧 (15耳)
本論文の要旨は平成 4 年11月, 第 2 回日本耳科学 会臨床学会に打いて発表した。

\section{文献}

1) Dawes JDK : The postero-superior quadrant. J Laryngol Otol 88 : 955 957, 1974.

2) Bhide A : Etiology of the retraction pocket in the posterior quadrant of the eardrum. Arch Otolaryngol $103: 707 \sim 711,1977$.

3) Thorurn IB : The pathogenesis of chronic otitis media. Proc Roy Med 61 : 395 399, 1968.

4) Bluestone CD, Paradise JL and Berry QC : Symposium on prophylaxis and treatment of middle ear effusions; $\mathbb{N}$ physiology of the eustachian tube in the pathogenesis and management of middle ear effusions. Laryngoscope $82: 1654 \sim 1670,1972$.

5）本庄 嚴: 耳管と中耳病態. 27～56頁, 進行印 刷出版, 京都, 1987.

6) Fujita A, Takahashi H, Honjo I, et al : Refractory otitis media with effusion from view points of eustachian tube dysfunction and nasal sinusitis. Am J Otolaryngol 94 : 187 190, 1993.

7) Tos M and Poulsen $G$ : Attic retractions following secretory otitis. Acta Otolaryngol $89: 479$ $\sim 486,1980$.

8) Sade J and Berco E : Atelectasis and secretory otitis media. Ann Otol Rhinol Laryngol 85 suppl $25: 66 \sim 73,1976$.

9) Buckingham RA and Ferrer JL : Observations of middle ear pressures, commentary with movie. Ann Otol Rhinol Laryngol 89 suppl $68: 56 \sim 61,1980$.

10）高橋晴雄：滲出性中耳炎と耳管. 耳鼻臨床 補 $22: 1 \sim 21,1988$.

11) Magnuson B: On the origin of the high negative pressure in the middle ear space. Am J Otolaryngol $2: 1 \sim 12,1981$.

12) Flisberg $K$ and Zsigmond $M:$ The size of the mastoid air cell system; planimetry direct volume determination. Acta Otolaryngol 60 : 23 29, 1965.

$$
\left.\begin{array}{l}
\text { 原稿受付 : 平成 } 5 \text { 年 } 6 \text { 月 } 17 \text { 日 } \\
\text { 原稿採択 : 平成 } 5 \text { 年 } 8 \text { 月 } 5 \text { 日 } \\
\text { 別刷請求先 : 藤田明彦 } \\
\text { 干 } 606 \text { 京都市左京区聖護院川原町 } 54 \\
\text { 京都大学医学部耳鼻咽喉科学教室 }
\end{array}\right)
$$

